\title{
ZNACZENIE LINKED DATA WOBEC WSPÓŁCZESNYCH TRENDÓW OPERACYJNEGO ZARZĄDZANIA PRODUKCJĄ
}

\author{
Magdalena Jurczyk-Bunkowska \\ Politechnika Opolska, Instytut Innowacyjności Procesów i Produktów \\ Ilona Pawełoszek \\ Politechnika Częstochowska, Wydział Zarządzania
}

\begin{abstract}
Streszczenie: W artykule zaproponowano zastosowanie technologii Linked Data, która jest jednym $\mathrm{z}$ aktualnych podejść do konstruowania praktycznych rozwiązań zarządzania wiedzą i informacją przedsiębiorstwa poprzez elastyczną integrację danych. Zidentyfikowano współczesne trendy rynkowe, wskazując, jak istotne w adaptacji do nich jest skuteczne i kompleksowe zarządzanie informacją. Odniesiono się do konieczności gromadzenia informacji na potrzeby zarządzania operacyjnego z różnych źródeł znajdujących sie w przedsiębiorstwie i jego otoczeniu. Bazując na badaniach literaturowych, określono warunki zastosowania Linked Data w zarządzaniu operacyjnym.
\end{abstract}

Słowa kluczowe: zarządzanie operacyjne, przetwarzanie wiedzy, Linked Data

DOI: $10.17512 /$ znpcz.2016.3.1.10

\section{Wprowadzenie}

Współczesną gospodarkę charakteryzuje duża zmienność i wynikająca z niej niepewność. Sytuacja taka wymaga nieustannej adaptacji zarządzania działalnością podstawową do warunków funkcjonowania otoczenia. Obok tradycyjnych czynników konkurencyjności, takich jak jakość, cena, elastyczność czy czas obsługi, kluczowego znaczenia nabiera zarządzanie wiedzą i predyspozycje do organizacyjnego uczenia się. Celem istnienia każdej organizacji jest zaspokojenie potrzeb klientów przez wytwarzanie określonych produktów. Działania związane bezpośrednio z wytwarzaniem tych produktów nazywane są operacjami i pełnią w każdej organizacji istotną rolę. Zarządzanie operacyjne jest funkcją zarządzania odpowiedzialną za wszystkie działania bezpośrednio dotyczące wytwarzania produktu, czyli gromadzenie rozmaitych składników wejściowych i przetwarzanie ich w planowane produkty końcowe (Waters 2001). Obejmuje ono tworzenie praktyk, które pozwalają na osiągnięcie możliwie wysokiego poziomu funkcjonowania danej organizacji w odniesieniu do produkcji, co wymaga nieustannego doskonalenia procesów. Zarządzanie operacyjne jest definiowane jako zarządzanie systemami i procesami, które tworzą wartość w postaci towarów i usług na drodze przekształcania wejść w pożądane wyjścia (Heizer, Render 2013). Pierwotnie pojęcie to odnoszone było przede wszystkim do produkcji przemysłowej, obecnie odnoszone jest również do działalności usługowej, co podkreśla definicja, w której zarządzanie operacyjne określa się jako projek- 
towanie, eksploatowanie i rozwijanie systemu, w którym odbywa się podstawowa produkcja lub prowadzona jest działalność usługowa (Jacobs, Chase 2012).

Aby funkcjonować w turbulentnym otoczeniu, kluczowe znaczenie mają kompetencje związane z przetwarzaniem informacji, takie jak: umiejętność jej pozyskiwania, przekazywania na zewnątrz w niezbędnym zakresie, ograniczenie formalizacji i umiejętność uczenia się (Perechuda 2000). Współczesne trendy rozwoju rynku wymagają poszukiwania rozwiązań umożliwiających przejmowanie wiedzy przez struktury przedsiębiorstwa i ograniczenie strat wynikających z płynności kadr. Systemy informatyczne w obszarze zarządzania operacyjnego powinny umożliwiać przechowywanie i dystrybucję informacji pochodzących z różnych źródel, posiadających różną strukturę i format. Oprócz wymienionych standardowych funkcji, powinny charakteryzować się dynamiką wyrażającą się w łatwości rozszerzania o nowe zasoby (w szczególności uwzględnianie nowych typów i źródeł zasobów) ze względu na ciągłą identyfikację nowych potrzeb informacyjnych. Obecnie, w celu praktycznej realizacji tej potrzeby, zalecane są koncepcje i technologie semantycznej sieci Web, które umożliwiają komputerom automatyczne przetwarzanie i rozumienie informacji zapisanej jako zbiór semantycznie połączonych danych (ang. Linked Data). Istotą tej koncepcji jest przedstawianie zasobów informacyjnych w sposób sformalizowany, który mogą zrozumieć zarówno ludzie, jak i maszyny.

Celem artykułu jest pokazanie możliwości zastosowania koncepcji Linked Data we wsparciu zarządzania działalnością operacyjną współczesnego przedsiębiorstwa, a szczególnie jego dostosowania do zmieniających się warunków funkcjonowania. W tym obszarze w ostatnich latach następują gwałtowne i daleko idące zmiany, które określa się mianem czwartej rewolucji przemysłowej (Przemysł 4.0) (Kagermann, Wahlster, Helbig 2013; Brettel i in. 2014, s. 37-44). Dlatego - dla właściwej realizacji zadań zarządzania operacyjnego, które zostały scharakteryzowane $\mathrm{w}$ punkcie drugim artykułu - należy szukać innowacyjnych, zaawansowanych rozwiązań informatycznych pozwalających sprostać tym wyzwaniom. W punkcie trzecim scharakteryzowano najważniejsze trendy, które kształtują nowe wymagania dla zarządzania operacyjnego. W kolejnej części naświetlono koncepcję i cel zastosowania Linked Data w kontekście zidentyfikowanych kierunków zmian, istotnych dla zarządzania operacyjnego. W podsumowaniu odniesiono się do efektów i warunków, które muszą być spełnione dla wdrożenia Linked Data w przedsiębiorstwie.

\section{Zadania zarządzania operacyjnego}

Zarządzanie operacyjne odnosi się głównie do planowania, organizowania i kontrolowania produkcji rozumianej jako wytwarzanie wyrobów lub świadczenie usług. Jest ono skoncentrowane na efektywnym przekształcaniu czynników wejścia w elementy wyjścia z systemu produkcyjnego. Dotyczy realizacji procesów biznesowych zmierzających do projektowania, wytwarzania (lub świadczenia usług), dostarczania odbiorcom produktów. Można zatem powiedzieć, że obejmuje przepływy rzeczowe, finansowe i informacyjne w łańcuchu tworzenia wartości. Im bardziej klienci przedsiębiorstwa są zadowoleni ze sposobu realizacji tych proce- 
sów i/lub są niższe ich koszty (także środowiskowe), tym lepsze jest zarządzanie operacyjne w przedsiębiorstwie.

Realizacja zadań zarządzania operacyjnego różni się w zależności od specyfiki produkcji; np. ze względu na powtarzalność produkcji wyróżnia się typ jednostkowy, seryjny i masowy; ze względu na organizację przebiegu produkcji: produkcję ciągłą i dyskretną; ze względu na relacje z klientami: produkcję na zamówienie indywidualne klienta i produkcję na magazyn (dla anonimowego klienta). Można jednak wymienić pewne klasy zadań w ramach zarządzania operacyjnego typowe dla wszystkich organizacji (Karlsson 2009):

1. Zrozumienie i rozwój strategicznych celów organizacji, aby wspierać jej długoterminowy wzrost. Tworzy to zbiór generalnych zasad podejmowania decyzji operacyjnych, który gwarantuje realizację strategii przedsiębiorstwa.

2. Projektowanie wykorzystania zasobów organizacji w sposób, który zapewnia uzyskanie pożądanych właściwości procesów, produktów i usług, układów zasilających, przepływu materiałów i półproduktów, organizacji pracy itp.

3. Planowanie i sterowanie przebiegiem operacji poprzez decydowanie, które z posiadanych zasobów operacyjnych powinny być wykorzystane, oraz zapewnienie ich właściwego wykorzystania. Obejmuje ono takie obszary, jak: zdolności produkcyjne, materiały, wyposażenie, procesy transformacji, projekty i jakość.

4. Doskonalenie wydajności poszczególnych działań, w kontekście usprawniania całych procesów, które stanowi obowiązek zarządzających produkcją na wszystkich szczeblach.

Termin ,zarządzanie operacyjne” obejmuje zatem szeroko rozumianą realizację codziennych zadań przedsiębiorstwa. Wraz ze wzrostem konkurencji na rynku i postępem technicznym znaczenie zarządzania operacyjnego, jak i zapotrzebowanie na narzędzia wspomagające pracę menedżerów w tym obszarze stale wzrasta.

\section{Identyfikacja nowych trendów w zarządzaniu operacyjnym}

Od współczesnych przedsiębiorstw wymaga się elastyczności, adaptacyjności, kreatywności i idącej za nią innowacyjności. Cechy te opisują organizację dynamiczną, która potrafi szybko samoorganizować się, samotransformować i dostosowywać do nowej sytuacji w otoczeniu oraz poprawiać efektywność realizowanych procesów poprzez pogłębianie wiedzy i rozwijanie kompetencji pracowników. Skutecznie działające przedsiębiorstwo potrafi radzić sobie ze zmianami, czego początkiem jest właściwa identyfikacja impulsów tych zmian, które mogą stanowić szanse dla jego rozwoju. Trendy rynkowe opisane w niniejszym punkcie powinny być zatem postrzegane jako zjawisko, na które przedsiębiorstwa reagują, jeśli chcą zwiększyć swoje szanse na przetrwanie i rozwój.

\section{Konkurowanie lańcuchów wartości}

Globalizacja dała firmom niemal nieograniczone możliwości nawiązywania współpracy i tworzenia sieciowych powiązań. Współcześnie konkurowanie doty- 
czy całych łańcuchów tworzenia wartości, poczynając od surowców, aż po firmy oferujące produkty końcowym odbiorcom (Ross 2013). Tym trudniejsze i bardziej złożone staje się sprawne zarządzanie działalnością operacyjną. W praktyce wymaga ono monitorowania i kontrolowania działań zarówno w przedsiębiorstwie, jak i poza jego granicami. Rozproszenie geograficzne dotyczące np. działów przygotowania produkcji, hal produkcyjnych, magazynów wymaga odpowiedniego środowiska komunikacji na potrzeby zarządzania operacyjnego, które umożliwi współpracę i koordynację prac prowadzonych na tym poziomie (Rudberg 2008, s. 91-106). W organizacjach sieciowych sprawność zarządzania zależy przede wszystkim od szybkości i wydajności, z jaką informacje mogą być wymieniane i wykorzystywane w procesach decyzyjnych. Są one często podejmowane w warunkach braku jasnych struktur i hierarchii organizacji, przy tymczasowości ustaleń co do uprawnień i obowiązków. Trzeba w tym miejscu zauważyć, że jakość informacji jest tak samo ważna dla tego typu organizacji, co zaufanie pomiędzy jej uczestnikami (Finley, Srikanth 2005, s. 30-37). Jednym z istotnych problemów jest np. dostęp do wskaźników opisujących zasoby produkcyjne partnerów biznesowych. Jest to konieczne dla koordynacji działań, natomiast wymaga umiejętności monitorowania sytuacji nie tylko w przedsiębiorstwie, ale także poza jego obszarem.

\section{Indywidualizacja produktów}

Kolejną kwestią jest proces tworzenia wartości dla współczesnego klienta. Coraz mniejsze znaczenie odgrywa cena, choć ciągle jest niezmiernie ważnym czynnikiem konkurencyjności. Natomiast coraz większej wagi, oprócz szybkości realizacji zlecenia, nabiera dopasowanie produktu do indywidualnych potrzeb jego odbiorcy. Trzeba zatem pozyskać wiedzę dotyczącą tego, jakich produktów oczekują klienci. Współcześnie nie mogą oni już być postrzegani i traktowani jako jednorodna grupa. Wymagają też znacznie więcej niż standardowego produktu. W ten trend wpisuje się strategia masowej indywidualizacji (ang. Mass Customization), której założeniem jest dostarczenie wyrobu jak najbardziej dopasowanego do potrzeb klienta przy zachowaniu kosztów zmiennych na poziomie produkcji masowej.

Dostosowanie i personalizacja staje się trendem we wszystkich dziedzinach życia, zarówno w odniesieniu do wyrobów, jak i usług (Piller, Müller 2004, s. 583-593). Realizowanie założeń tego typu produkcji wymaga zaangażowania konsumenta $\mathrm{w}$ proces tworzenia wartości. Bierze on udział $\mathrm{w}$ definiowaniu oraz konfigurowaniu czy też modyfikowaniu przedstawionych przez producenta rozwiązań. Wymaga to narzędzi zorientowanych na szybką i skuteczną wymianę informacji i wiedzy pomiędzy klientem a producentem. Zaoferowanie produktu spełniającego oczekiwania wymaga szczegółowej i rozbudowanej komunikacji z klientem. Jest ona zazwyczaj realizowana na niższych szczeblach decyzyjnych, np. rozmowy handlowców, serwisantów itp. Przedsiębiorstwa, dysponując często znacznymi zasobami wiedzy, nie są jej w stanie wykorzystać, ponieważ tworzone przez pracowników własne, niestandardowe rozwiązania wspomagające ich codzienną pracę nie są możliwe do zintegrowania z systemami CRM czy ERP działającymi w skali przedsiębiorstwa. 


\section{Powszechność systemów informatycznych}

Technologie informacyjne, bardziej niż jakikolwiek inny czynnik, zmieniły w ostatnich latach fundamenty zarządzania operacyjnego. Wykorzystanie zintegrowanych systemów informatycznych do wspomagania większości obszarów funkcjonowania organizacji powoli staje się codziennością. Poprzez zintegrowane systemy zarządzania przedsiębiorstwa w sposób uporządkowany zarządzają procesami biznesowymi. Gromadzą, przetwarzają, rejestrują i dokonują selekcji danych oraz integrują swoje systemy z kooperantami i klientami.

Odbywa się to w rzeczywistości coraz bardziej złożonych i tymczasowych systemów nastawionych na ciągły wzrost elastyczności produkcji. Dlatego stosowane rozwiązania idą $\mathrm{w}$ kierunku otwartych, skalowalnych systemów działających w chmurze czy wspomagania decyzji poprzez analizy dużych zbiorów danych (ang. Big Data). Celem jest stworzenie tzw. inteligentnej fabryki (ang. Smart Factory), która umożliwia produkcję pod indywidualne potrzeby klientów przy wysokim poziomie automatyzacji i samooptymalizacji. Tego rodzaju rozwiązania wymagają analizy dużych ilości danych w czasie rzeczywistym. Łączenie się organizacji z klientami oraz wyspecjalizowanymi jednostkami, np. projektowymi, marketingowymi, logistycznymi, finansowymi itp., będzie wymagało o wiele dalej idącej integracji niż dotychczasowa, nawet ta oferowana przez systemy ERP II. Dlatego coraz większego znaczenia nabierają systemy umożliwiające analizę danych, zarówno tych ustrukturyzowanych, jak i nieustrukturyzowanych.

\section{Rozszerzanie zakresu obsługi klienta}

Jednym z często wykorzystywanych kierunków poprawy konkurencyjności przedsiębiorstwa staje się obsługa klienta, a dokładnie - rozszerzanie jej zakresu. Wobec nasycenia rynku produktami porównywalnymi ze względu na cenę i jakość oraz niepewności co do efektów reklamy i promocji obsługa klienta staje się elementem przewagi rynkowej. Na przykład jakość produktu postrzegana jest również przez pryzmat poziomu doradztwa, cena przez warunki finansowania, dostępność przez różnorodność kanałów dystrybucji itp. Firmy nastawiają się już od jakiegoś czasu na tworzenie długotrwałych relacji z klientami. Obecnie rozwiązania informatyczne w tym zakresie, takie jak e-commerce, CRM, są już dostępne nawet dla mikroprzedsiębiorstw. Strona internetowa, newslettery czy nawet obecność w mediach społecznościowych należą do standardu.

Firmy włączają się w życie swoich klientów, np. nie zapominają o ich urodzinach, obserwują życie poprzez media społecznościowe i wykorzystują różne inne środki dla długofalowego pielęgnowania relacji z potencjalnym klientem (ang. Lead Nurturing), tak żeby w momencie podejmowania decyzji zakupowej wybrał oferowany przez określoną firmę produkt (Rosenbröijer 2014). Stosowanie tego typu podejścia generuje również konieczność mocnego powiązania działalności marketingowej z działalnością operacyjną przedsiębiorstwa. Wymaga to jednak narzędzi wspomagających nie tylko administrowanie danymi klientów, ale również ich preferencjami, możliwościami i doświadczeniami zakupowymi itp. $Z$ tego względu wyzwaniem dla producentów jest tworzenie kompleksowych rozwiązań, 
obejmujących zarówno produkt, jak i jego sprzedaż oraz serwis. Ponadto trzeba w kontekście kompleksowej obsługi klienta zastanowić się nad modelem określania rentowności produktu. Oprócz szacowania kosztów produktu wyzwaniem dla zarządzania operacyjnego staje się również pomiar efektywności funkcjonowania systemu oraz monitorowanie jakości produktu i zaspokojenia potrzeb klientów.

$\mathrm{Z}$ zagadnieniem rozszerzenia zakresu obsługi klienta można powiązać również konieczność zarządzania operacyjnego uwzględniającego koncepcję zrównoważonego rozwoju. Zmniejszanie wykorzystania energii i surowców naturalnych, zrównoważone obciążenie zasobów, właściwe warunki zapewnione pracownikom produkcyjnym, jak również monitoring eksploatacji i recyklingu produktów stają się dla coraz bardziej świadomych odbiorców nie tylko medialnym dodatkiem, ale rzeczywistym kryterium wyboru oferty. Wiąże się to nie tylko z działalnością wizerunkową firmy, ale także decyzjami podejmowanymi w ramach zarządzania operacyjnego.

\section{Implementacja Linked Data}

Rozwój Internetu umożliwił stworzenie globalnej przestrzeni informacyjnej złożonej z połączonych dokumentów. Coraz częściej sieć WWW jest traktowana jako baza, $\mathrm{z}$ której można wydobyć zestawienia danych zaczerpniętych $\mathrm{z}$ różnych stron internetowych. Przykładami takich zastosowań Internetu mogą być porównywarki cenowe towarów, usług finansowych, transportowych itp.

Aby można było wydobyć dane $\mathrm{z}$ różnorodnych dokumentów, niezbędne jest ich opublikowanie w odpowiedni sposób, umożliwiający oddzielenie „surowych” danych od innej treści, np. instrukcji formatowania, skryptów, elementów multimedialnych. Kolejną ważną kwestią obok wyodrębnienia danych jest rozpoznanie, czego dotyczą, i połączenie tematyczne zestawień z różnych źródeł.

Definicja, którą można znaleźć na portalu http://linkeddata.org/, mówi, iż Linked Data polega na wykorzystaniu sieci Web do łączenia powiązanych znaczeniowo danych, które nie były dotąd połączone, lub użyciu sieci Web, aby zmniejszyć bariery łączenia danych, które są obecnie połączone za pomocą innych metod.

Linked Data to stosunkowo nowy paradygmat publikowania informacji, który jest praktycznym krokiem w celu realizacji wizji Semantic Web. Obejmuje on zbiór dobrych praktyk publikowania i łączenia strukturalnych danych w sieci. Te najlepsze praktyki przedstawił Tim Berners-Lee (Berners-Lee 2006), a obejmują one następujące wytyczne:

1. Użycie identyfikatorów URI (Uniform Resource Identyfikator) do jednoznacznego nazwania rzeczy.

2. Wykorzystywane URI powinny być zgodne ze standardem Hypertext Transfer Protokół (HTTP) (Fielding 1999), aby użytkownicy mogli swobodnie się wśród nich poruszać i sprawdzać ich zawartość.

3. Kiedy użytkownik sprawdza URI, powinien on dostarczyć użytecznej informacji poprzez wykorzystanie standardów takich jak RDF czy SPARQL.

4. Dokumenty powinny zawierać łącza URI do różnorodnych zasobów, aby możliwe było odkrywanie różnych treści. 
Podstawową ideą Linked Data jest zastosowanie ogólnej architektury sieci WWW do zadań współdzielenia strukturalnej informacji w skali globalnej. Aby zrozumieć zasady Linked Data, ważne jest zapoznanie się z architekturą klasycznej sieci Web opartej na dokumentach połączonych poprzez hiperłącza.

Pierwsza $\mathrm{z}$ wyżej wymienionych wytycznych wydaje się być najistotniejsza i związana z następnymi. Sugeruje ona używanie URI do identyfikacji nie tylko dokumentów i treści cyfrowych, ale także obiektów świata rzeczywistego i koncepcji abstrakcyjnych. Identyfikacja za pomocą URI może zatem dotyczyć ludzi, miejsc, rzeczy, a także relacji pomiędzy nimi - np. relacja znajomości pomiędzy ludźmi, zbiór rzeczy określonego typu i przynależność do zbioru, cechy danej rzeczy. Wszystkie te koncepcje mogą być zidentyfikowane za pomocą unikalnego w skali Internetu URI, który jest adresem prowadzącym do opisu danej rzeczy lub pojęcia. Zasada użycia URI daje możliwość rozszerzenia zasięgu sieci Web nie tylko do dokumentów, ale także obiektów i koncepcji świata rzeczywistego.

Kolejna zasada dotycząca stosowania protokołu HTTP jako uniwersalnego mechanizmu dostępu propaguje użycie tego standardu, który jest najbardziej rozpowszechniony i daje użytkownikom możliwość łatwego poruszania się pomiędzy dokumentami sieci Web opisującymi osoby, rzeczy i koncepcje. Użycie powszechnie wykorzystywanych standardów, takich jak HTTP i HTML, ma decydujący wpływ na skalowalność aplikacji. Trzecia zasada Linked Data propaguje użycie jednego modelu danych do publikacji strukturalnych danych w sieci Web. Tym standardem jest Resource Description Framework (RDF), czyli prosty grafowy model danych. Czwarta zasada zaleca, aby tworzyć hiperłącza pomiędzy różnymi typami rzeczy (nie tylko dokumentami sieci Web, a na przykład pomiędzy osobami, miejscami, zdarzeniami lub miejscami i organizacjami).

W odróżnieniu od tradycyjnej sieci Web w środowisku Linked Data hiperłącza mają swoje dokładnie zdefiniowane typy i opisują relacje pomiędzy określonymi typami rzeczy. Na przykład relacja typu „znajomy” może łączyć dwie osoby, natomiast relacja „w pobliżu” może dotyczyć dwóch miejsc lub miejsca i osoby.

Sieć Web jest zbudowana w oparciu o niewielki zbiór prostych standardów, którymi są: URI (Uniform Resource Identifier), będący mechanizmem globalnej identyfikacji zasobów (Berners-Lee, Fielding, Masinter 1998), HTTP, jako uniwersalny mechanizm dostępu do danych, oraz HTML (Raggett, Le Hors, Jacobs 1999) - rozpowszechniony standard publikowania treści.

Podsumowując, można stwierdzić, iż zasady Linked Data formułują podstawy do rozszerzania sieci Web o globalną przestrzeń danych w oparciu o już istniejącą architekturę, która zakłada, że połączone dokumenty mogą się znajdować na różnych serwerach.

Dokumenty to niestrukturalne lub semistrukturalne zbiory danych, które obecnie zyskują na wadze i coraz częściej dostrzega się potencjał wykorzystania zawartej w nich informacji. Podobnie jak kilkanaście lat temu rozwijano podejścia do integracji relacyjnych baz danych, tak obecnie wiele wysiłków skupia się na bazach dokumentów. Jak dotąd stworzono szereg rozwiązań wspomagających problemy integracji danych z różnych źródeł. Były one przez lata wdrażane przede wszystkim w dużych organizacjach. Obecnie w obszarze integracji danych wyko- 
rzystywane są rozwiązania takie jak: hurtownie danych (ang. Data Warehouse), zarządzanie danymi podstawowymi (ang. Master Data Management - MDM), repozytoria metadanych (ang. Metadata Repositories, słowniki kontrolowane (ang. Controlled Vocabularies), wspomagająco także przetwarzanie języka naturalnego (ang. Natural Language Processing - NLP).

Funkcjonowanie wyżej wymienionych systemów i technologii nie rozwiązało do końca kluczowych problemów efektywnego wykorzystania danych zawartych w dokumentach. Jak pokazuje praktyka, przedsiębiorstwa wciąż borykają się z problemem zarządzania informacją.

Architektura od lat stosowana w sieci Web, polegająca na łączeniu danych, wydaje się być obecnie najbardziej elastycznym i sprawdzonym rozwiązaniem integracyjnym w przypadku dużej ilości różnorodnych danych. Technologia Linked Data czerpie najlepsze cechy z wyżej wymienionych popularnych rozwiązań, dodatkowo bazuje na dobrze ugruntowanych standardach stosowanych powszechnie w Internecie.

Aby koncepcja semantycznej sieci Web mogła zostać przeniesiona na grunt organizacji, niezbędne jest zastosowanie technologii Linked Data i wymaganych przez nią standardów, bowiem są one warunkiem interoperacyjności zbiorów danych tworzonych przez różne jednostki. Jednakże równie ważnym czynnikiem sukcesu projektów Linked Data w przedsiębiorstwach jest praktyczne stosowanie odpowiedniej polityki informacyjnej. Tworzenie i współdzielenie informacji powinny być nieodłącznie ze sobą powiązane. Jeśli tworzony jest jakiś dokument, powinien być skonstruowany w ten sposób, aby było możliwe jego wykorzystanie przez innych członków organizacji. Dane zawarte w nowo tworzonym dokumencie powinny mieć powiązanie semantyczne $\mathrm{z}$ różnymi obszarami funkcjonowania przedsiębiorstwa. Krytycznym czynnikiem wydaje się uzyskanie akceptacji i zrozumienia całego zespołu pracowników w tym względzie. Aby zrealizować cel połączonych danych, konieczna jest ogólnie obowiązująca reprezentacja danych i jej uwzględnianie podczas tworzenia dokumentów. W praktyce oznacza to konieczność przygotowywania dokumentów uzupełnionych o metadane (zgodne ze schematem RDFa lub mikroformatami), które mogą być dynamicznie przetwarzane, aby wydobyć znaczenie treści zawartej w dokumentach. $Z$ technicznego punktu widzenia używane edytory tekstu lub danych tabelarycznych powinny być zaopatrzone w możliwość dodania takich anotacji. W przypadku dokumentów opartych na otwartych schematach danych, takich jak XML, możliwe jest ich uzupełnianie o dodatkowe znaczniki niosące informację o znaczeniu danych zawartych w ich obrębie. Popularne nowoczesne formaty dokumentów, takie jak docx lub xlsx używane w pakiecie MS Office (a także inne nowoczesne formaty oparte na XML), mogą być rozszerzane o dodatkowe przestrzenie nazw, zarazem znaczniki. Przykładem narzędzia służącego do semantyzacji dokumentów arkusza kalkulacyjnego Excel jest produkt firmy Cambridge Semantics - pod nazwą Anzo (Cambridge Semantics b.r.). Umożliwia on dodanie do komórek arkusza kalkulacyjnego odwołań do przestrzeni nazw używanych w przedsiębiorstwie, którymi mogą być np. słowniki czy ontologie. Podobnie w przypadku dokumentów sieci Web tworzonych w systemach zarządzania treścią funkcjonujących online (np. Wordpress, 
Drupal czy Joomla) możliwe jest zainstalowanie rozszerzeń semantycznych, czyli dostarczenie możliwości dodawania do tekstu znaczników opisujących zawarte w nim dane.

Oczywiście Linked Data w przedsiębiorstwie dotyczy nie tylko zbiorów dokumentów, ale także strukturalnych źródeł danych - takich jak relacyjne bazy danych będące częścią systemów informatycznych przedsiębiorstwa (np. modułów systemu ERP). Pola w bazie danych (nazwy kolumn tabel) mogą być łączone znaczeniowo (mapowane) ze standardowymi słownikami opisującymi schematy danych. Jednym $\mathrm{z}$ takich standardów metadanych opisujących pola $\mathrm{w}$ bazach danych jest Open Data Element Framework (O-DEF) (OpenGroup 2015). Dostarcza on kodów, za pomocą których można zidentyfikować znaczenie nazw tabel i pól w bazach.

W przypadku opisu dokumentów najczęściej pracownicy korzystają z niestandardowych słowników, skonstruowanych na swoje potrzeby. Pracownicy, nie mając doświadczenia w inżynierii wiedzy, mogą posługiwać się mniej formalnymi metodami, np. tagowaniem zasobów informacyjnych. Oczywiście w przedsiębiorstwie realizującym koncepcję połączonych danych jest miejsce na własne schematy wiedzy, jednakże zbiór używanych tagów powinien być ściśle zdefiniowany i możliwy do mapowania $\mathrm{z}$ innymi schematami używanymi w przedsiębiorstwie. Oznacza to, iż powinna być zapewniona możliwość zidentyfikowania tych samych terminów w różnych używanych słownikach.

Aby rozwiązania oparte na Linked Data mogły prawidłowo funkcjonować, niezbędny jest nadzór nad tworzeniem i utrzymaniem schematów danych. Wiele przedsiębiorstw stosuje podejście oparte na powierzeniu tych zadań społeczności wybranych pracowników. Podejście społecznościowe doskonale sprawdziło się w Internecie w przypadku Wikipedii (Skolik 2008).

\section{Cel i znaczenie zastosowania Linked Data w zarządzaniu operacyjnym}

Odpowiadając na wymagania współczesnego rynku, w decyzjach zarządzania operacyjnego można zaobserwować zjawiska w skali mikro, przypominające charakterem te zaobserwowane $\mathrm{w}$ globalnej sieci Web. Jak pokazują badania zawarte $\mathrm{w}$ raportach firmy KPMG (KPMG 2015), wraz ze wzrostem dojrzałości przedsiębiorstw przejawiającej się w przechodzeniu od gromadzenia wiedzy do tworzenia wartości można zaobserwować wzrost złożoności zadań analitycznych. W pokazanych w poprzednim punkcie przykładach można zauważyć problem wzrostu liczby wykorzystywanych źródeł danych. Często działania poszczególnych działów organizacji prowadzą do powstawania tzw. silosów wewnątrz organizacji. Są to zbiory dokumentów, czyli repozytoria pozostające pod kontrolą jednego działu, do których pracownicy innych działów mają utrudniony dostęp. Tworzenie silosów danych może mieć podłoże techniczne wynikające $\mathrm{z}$ braku dobrych rozwiązań integracyjnych, może też być wynikiem kultury organizacyjnej. Gdy każdy dział ma inne cele, zakres odpowiedzialności i priorytety, w organizacji panuje atmosfera konkurencji zamiast współpracy. Przełamanie tego typu podejścia to konieczność wykorzystania bardziej skomplikowanych technik w innowacyjnych obszarach biznesu oraz poprawa jakości i powtarzalności implementowanych rozwiązań. 
Jak wskazano, w przedsiębiorstwie chcącym skutecznie adaptować się do trendów rynkowych informacje niezbędne do płynnego funkcjonowania gromadzone są w różnych źródłach. Są one dostępne oczywiście w zintegrowanych systemach informatycznych, takich jak: ERP, CRM, SCM, które opisują procesy biznesowe, produkty, klientów, pracowników. Jednak informacje na temat tego samego obiektu znajdują się w różnych bazach danych lub dokumentach, opisując go z różnych perspektyw. Aby uzyskać holistyczny, a zarazem szczegółowy wgląd w to, co dzieje się $\mathrm{w}$ przedsiębiorstwie, niezbędne jest semantyczne połączenie danych $\mathrm{z}$ różnych źródeł opisujących to samo zjawisko (np. proces biznesowy od strony logistycznej, kadrowej, wykorzystanych zasobów). Ideę integracji różnych systemów z pomocą technologii Linked Data prezentuje Rysunek 1.

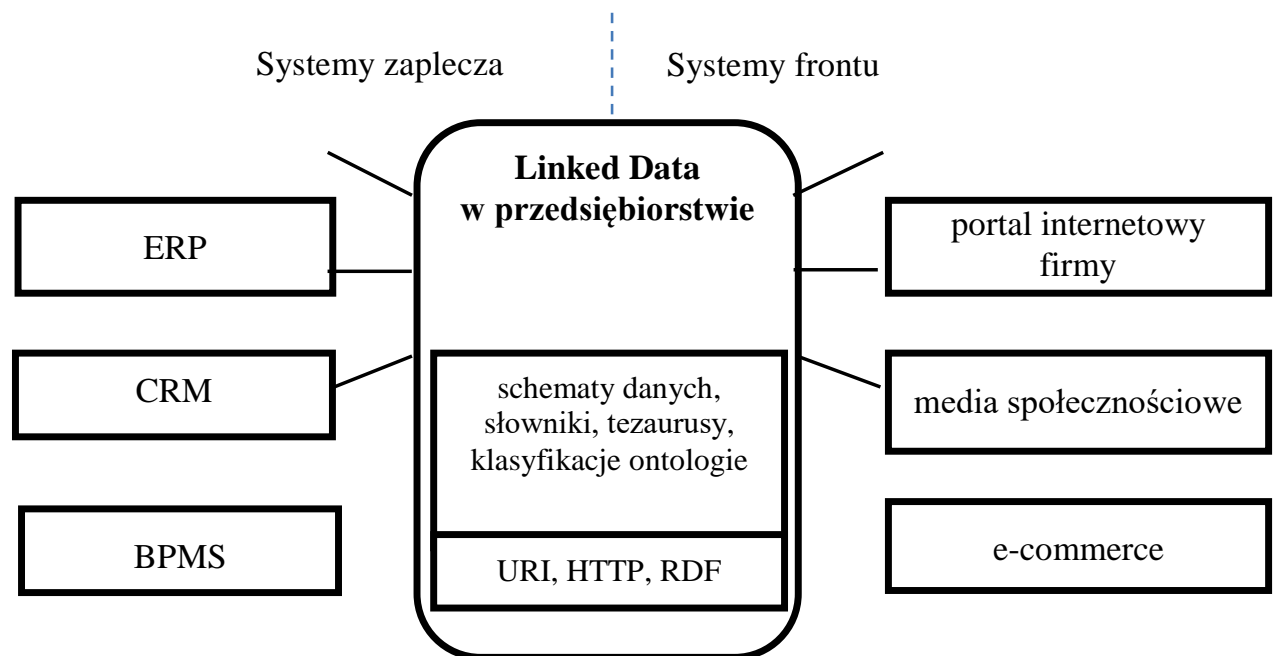

\section{Rysunek 1. Integracja systemów przedsiębiorstwa za pomocą Linked Data}

Źródło: Opracowanie własne

W organizacjach inteligentnych pracownicy wiedzy często tworzą własne repozytoria potrzebnych im danych, najczęściej w tym celu wykorzystywane są arkusze kalkulacyjne, a także pliki różnych formatów tworzone przez tzw. aplikacje cienia. Tworzone pliki zawierają opisy różnych ważnych z punktu widzenia przedsiębiorstwa zagadnień z perspektywy danego pracownika. Dla pracowników są one niezwykle cenne, gdyż pomagają organizować dane w sposób zorientowany na określone zadania użytkownika. Jednakże te pomocne narzędzia $z$ punktu widzenia zarządzania wiedzą przedsiębiorstwa stanowią problem. Pracownicy tworzą własne struktury danych i nie jest możliwe zapewnienie spójności informacji w nich zawartych, ze względu na częste dokonywanie zmian (Weber, Pohl, Steinbach 2004, s. 77-82). To sprawia, iż przydatność wiedzy zawartej w arkuszach kalkulacyjnych $\mathrm{i}$ innych podobnych aplikacjach jest znikoma lub żadna z punktu widzenia całego przedsiębiorstwa. A właśnie ta wiedza może okazać się kluczowym czynnikiem powodzenia w adaptacji do wskazanych trendów współczesnego rynku. 


\section{Podsumowanie i wnioski}

Systemy produkcyjne współczesnych przedsiębiorstw muszą sprostać wymaganiom coraz większej elastyczności. Jest to niemożliwe bez sprawnie działającego systemu informacyjnego obejmującego już nie tylko samo przedsiębiorstwo, ale także jego otoczenie. Wymaga to zaawansowanych rozwiązań z zakresu technologii informatycznych, jakim jest m.in. Linked Data. Efektywność zarządzania informacją $\mathrm{w}$ przedsiębiorstwie dotyczy nie tylko dostępu do informacji, ale również jej jakości. Musi być ona przedstawiona w sposób czytelny, by w praktyce wspierać decyzje zarządzających. W obliczu dużej liczby źródeł problemem staje się przeciążenie informacją. Technologia Linked Data oferująca radykalnie nowe podejście do publikacji i współdzielenia informacji poprzez stworzenie przestrzeni informacyjnej łączącej dane ze źródeł strukturalnych i niestrukturalnych w przedsiębiorstwie, a także zewnętrznych, takich jak strony sieci Web, niweluje to zjawisko. Celem jej zastosowania jest dostarczenie zarządzającemu inteligentnego narzędzia umożliwiającego:

- kompleksową reakcję na zmiany warunków działalności operacyjnej,

- opanowanie coraz bardziej złożonych procesów produkcyjnych i biznesowych,

- efektywne tworzenie powiązań z otoczeniem.

Podstawową zaletą Linked Data jest elastyczność i otwartość na rozbudowę oraz interoperacyjność z różnymi aplikacjami. Niemniej wdrożenie jej w przedsiębiorstwie wymaga skutecznego zarządzania wiedzą, a kluczowym czynnikiem powodzenia wydaje się być współudział pracowników zaangażowanych w tworzenie struktur wiedzy organizacji, który jest zdeterminowany podejściem do zarządzania zasobami ludzkimi.

\section{Literatura}

1. Berners-Lee T. (2006), Linked Data - Design Issues, http://www.w3.org/DesignIssues/ LinkedData.html (dostęp: 10.01.2016).

2. Berners-Lee, T., Fielding R., Masinter L. (1998), RFC 2396 - Uniform Resource Identifiers (URI): Generic Syntax, http://www.isi.edu/in-notes/rfc2396.txt (dostęp: 10.01.2016).

3. Brettel M., Friederichsen N., Keller M., Rosenberg M. (2014), How Virtualization, Decentralization and Network Building Change the Manufacturing Landscape: An Industry 4.0 Perspective, "International Journal of Mechanical, Aerospace, Industrial and Mechatronics Engineering", Vol. 8, No. 1.

4. Cambridge Semantics (b.r.), https://supportcenter.cambridgesemantics.com/support/ downloads (dostęp: 10.01.2016).

5. Fielding R. (1999), Hypertext Transfer Protocol - http/1.1. Request for Comments: 2616 , http://www.w3.org/Protocols/rfc2616/rfc2616.html (dostęp: 10.01.2016).

6. Finley F., Srikanth S. (2005), 7 Imperatives for Successful Collaboration, "Supply Chain Management Review", January/February, Vol. 9, Issue 1.

7. Heizer J., Render B. (2013), Operations Management (11 edition), Pearson, b.m.

8. Jacobs F.R., Chase R. (2012), Operations and Supply Chain Management: The Core (3rd Edition), McGraw-Hill/Irwin Series Operations and Decision Sciences, New York.

9. Kagermann H., Wahlster W., Helbig J. (2013), Recommendations for Implementing the Strategic Initiative Industrie 4.0, National Academy of Science and Engineering, Frankfurt am Main. 
10. Karlsson C. (2009), Researching Operations Management, [w:] Karlsson C. (ed.), Researching Operations Management, Taylor \& Francis, New York.

11. KPMG (2015), Zrozumieć dane. Od wiedzy do wartości, KPMG Advisory https://www.kpmg. com/PL/p1/IssuesAndInsights/ArticlesPublications/Documents/2015/Raport-KPMGInternational-Zrozumiec-dane-od-wiedzy-do-wartosci.pdf (dostęp:10.04.2016).

12. OpenGroup (2015), Open Data Element Framework (O-DEF), http://www.opengroup.org/ edinburgh2015/proceedings/iot-odef (dostęp: 10.01.2016).

13. Perechuda K. (2000), Zarzadzanie przedsiębiorstwem przyszłości. Koncepcje, modele, meto$d y$, Agencja Wydawnicza Placet, Warszawa.

14. Piller F.T., Müller M. (2004), A New Marketing Approach to Mass Customisation, "International Journal of Computer Integrated Manufacturing", Vol. 17, No. 7.

15. Raggett D., Hors Le A., Jacobs I. (1999), HTML 4.01 Specification - W3C Recommendation. http://www.w3.org/TR/html401/ (dostęp: 10.01.2016).

16. Rosenbröijer C.J. (2014), Customer Relationship Management and Business Analytics: A Lead Nurturing Approach, Proceedings of DYNAA 5.1., Atlanta.

17. Ross D.F. (2013), Competing Through Supply Chain Management: Creating MarketWinning Strategies Through Supply Chain Partnerships, Springer Science \& Business Media, New York.

18. Rudberg M. (2008), West, Global Operations Strategy: Coordinating Manufacturing Networks, "Omega", Vol. 36, Issue 1.

19. Skolik S. (2008), Spoleczne tworzenie Wikipedii. Perspektywa aktywnego uczestnika projektu, [w:] Sokołowski M. (red.), Media i społeczeństwo. Nowe strategie komunikacyjne, Wydawnictwo Adam Marszałek, Toruń.

20. Waters D. (2001), Zarządzanie operacyjne. Towary i ustugi, Wydawnictwo Naukowe PWN Warszawa.

21. Weber C., Pohl M., Steinbach M. (2004), New Ideas for Knowledge Management in Product Development Projects, [w:] Marjanovic D. (ed.), Proceedings of the 8th International Design Conference, Croatia, 18-21 May, Dubrovnik.

\title{
SIGNIFICANCE OF LINKED DATA IN THE LIGHT OF CURRENT TRENDS IN OPERATIONS MANAGEMENT OF PRODUCTION
}

\begin{abstract}
The paper presents application of Linked Data technology, which is one of current approaches to construction of practical solutions for knowledge and information management in enterprises by flexible data integration. Contemporary market trends were identified, showing the importance of effective and comprehensive information management. Reference was made to necessity of gathering information for the needs of operations management from different sources located as well inside as outside of the enterprise in its environment. Based on literature review, the conditions of applying Linked Data in operations management were outlined.
\end{abstract}

Keywords: operations management, knowledge processing, Linked Data 